\title{
Risk and Household Grain Management in Developing Countries
}

\author{
Albert Park \\ Department of Economics, University of Michigan, Ann Arbor, MI 48109 \\ alpark@umich.edu
}

Revised December 2005

\begin{abstract}
A dynamic model is presented of a household's joint production, storage, and trade decisions when facing transaction costs and risk in prices and yields. Grain management decisions balance the goals of maximizing profits and reducing consumption price risk. Model solutions calibrated to Chinese data show that grain's consumption role makes it an attractive form of precautionary saving even when households have access to credit, the joint nature of production and savings decisions limits the income loss associated with risk-coping, and the desire to store grain can explain why subsistence households are frequently net purchasers but rarely net sellers of grain.
\end{abstract}

JEL codes: O12, Q12, C61

Keywords: risk, development, grain, China 


\section{Risk and Household Grain Management in Developing Countries}

This paper sheds new light on one of history's oldest economic problems - how to ensure subsistence consumption in a world of great vicissitudes. For rural households in developing countries, grain is the key staple and a main consumption good. Households produce, store, and purchase grain to ensure that they can meet their consumption needs in a world of uncertain yields and prices. In many regions, such as those surveyed by the author in northwest China, households hold sizable grain stocks and devote much land and labour to grain cultivation despite grain's inferior asset and production return. Highly variable rainfall and isolated markets lead to considerable yield and price risk as well as nontrivial transaction costs in market exchange. Exposure to aggregate yield risk (i.e., regional shocks), in particular, leads to greater reliance on own assets to smooth consumption, since mutual insurance schemes break down when shocks are correlated across network members. In isolated markets, grain is likely to be expensive when the harvest is poor and the household is in greatest need of purchasing grain, giving households added incentive to store grain as an ex ante hedge against consumption price risk.

Despite the canonical nature of the problem, previous models fall considerably short of capturing the main aspects of household grain management strategies under uncertainty. Largely for reasons of tractability, models have been partial in nature, looking only at one grain management option--production (Finkelshtain and Chalfant, 1991; Fafchamps, 1992) or storage (Renkow, 1990; Saha and Stroud, 1994; Saha, 1994). Household grain storage models have restricted attention to one type of risk, either price risk or yield risk, and have treated the dynamic nature of the storage decision, especially price expectations, in an ad hoc fashion. ${ }^{1}$ Models of consumption smoothing have highlighted the importance of precautionary savings, but have not addressed why and under what circumstances such savings are held in specific assets (Deaton, 1990, 1991). Recent empirical work using data from India and Africa finds that grain buffer 
stocks are the most important form of saving used to smooth income shocks ex post (Lim and Townsend, 1998; Udry, 1995, Fafchamps, Udry, and Czukas, 1998). But formal models have not explained why households prefer to store grain. For example, Binswanger and Rosenzweig (1993) are unable to explain the large amount of grain and other liquid assets held by Indian households using traditional portfolio theory. In this paper, I argue that the limitations of previous work have led to an incomplete understanding of the state-contingent, joint nature of household risk-coping strategies and to biased inferences about both behavior and its welfare implications.

This paper presents the first complete model of household grain management decisions under uncertainty. It is complete in the sense that it captures the multiplicity of grain management options--storage, production, trade, and consumption - in a full dynamic specification; accounts for both yield and price uncertainty; explicitly models the grain market to generate realistic price expectations; and allows for positive transaction costs for market exchange. The model is parameterized to reflect the production and marketing environment in northwest China, based on survey data collected by the author in 1993 . The stochastic dynamic programming model extends standard models of precautionary saving in several ways. Instead of simply deciding how much wealth to save each period given exogenously determined income realizations (one state and one control), the household considers its cash wealth, grain availability, and current grain market conditions to decide the following: purchase or sell grain, divide available grain net of market transactions between consumption and storage, divide available financial wealth between purchases of the marketed good and bonds, and allocate the fixed resource between grain and cash crop production to be harvested next period (three states and four controls). Income is thus treated as endogenous. By allowing for asset holding, the model also extends existing models of risk and production.

Model simulations successfully replicate key features of observed behavior. A tension emerges between the household's desire to maximize income as a producer and portfolio investor, 
and to reduce its exposure to uncertainty that may jeopardize its consumption of grain as a consumer. Simulation results provide new insights into all three aspects of household grain management behavior: asset choice, production, and marketing. Here, we highlight the most important findings.

First, grain storage is held as a price hedge, not in lieu of credit or other ex-post consumption-smoothing mechanisms. Improving rural credit access is unlikely to lead farmers to reduce precautionary grain storage. On the other hand, without price risk, grain storage disappears with or without credit access. Thus, because simple models of precautionary saving overlook the risk-hedging properties of specific assets, they may lead to erroneous predictions about the effect of credit and insurance on precautionary saving. Understanding such behavior has important welfare implications. The precautionary desire to hold grain or liquid financial assets may prevent households from undertaking productive investments, especially those that are irreversible (Fafchamps and Pender, 1997). On-farm grain storage is an idle asset which is not intermediated for productive use elsewhere in the economy as are financial assets, so specific asset choices by households may have implications for aggregate investment and growth. Precautionary savings have been shown to be a potentially important source of aggregate wealth accumulation in developed countries (Caballero, 1991; Carroll, 1994).

Second, we find that the production response to risk depends on both the amount and composition of the household's starting wealth, but is unlikely to result in large expected income losses. The first part of this result extends the general finding that sufficiently wealthy households make production decisions as if risk were absent (Zeldes, 1989; Morduch, 1990) by considering the consumption price-hedging properties of specific assets. The second part of the result is due to the joint nature of asset and production decisions. Since the household has multiple mechanisms to cope with price risk, i.e., grain storage or grain production, when the relative cost of one mechanism is high, the households shifts to the other. This effectively bounds the expected 
income loss associated with production decisions. According to simulations of the calibrated model, the expected income of risk-coping households differs from profit-maximizing income by less than $2 \%$ on average. This result informs a contested issue in the literature. Several papers have pointed out inefficient agricultural production behavior, e.g., crop choice, technology adoption, and plot diversification, for the sake of income smoothing (see Morduch (1995) for a summary), but the magnitude of such effects are not well-established (Kochar, 1995). Walker and Ryan (1990), for instance, conclude that there is no compelling evidence that households in the ICRISAT villages in India make inefficient production decisions in response to risk.

Third, the model provides an explanation for why poor, subsistence farmers are frequently observed to purchase but not sell grain on the market (Barrett and Dorosh, 1996). This behavior results from the non-negativity of grain storage and the consumption price-hedging motive for grain storage. Households have no choice but to purchase grain if they are stocked out of grain in a bad year but can always store surplus grain in a good year. With a negative yieldprice correlation characteristic of isolated markets, when grain is in surplus, its price is likely to be low. In such circumstances, grain sales are less attractive, grain's asset return is maximized, and the expected return to grain production is low. These factors lead the household to store rather than sell surplus grain, while reducing grain sown area.

The paper is organized as follows. Section 1 presents the model, formalizing the household's optimization problem and price determination in the grain market. Section 2 discusses the model parameterization to the economic environment faced by rural households in northwest China and the algorithm for solving the model using numerical methods. Section 3 presents the main results. It describes a representative household's grain management decisions (policy rules) under certainty and uncertainty, summarizes simulation results for the base case, and presents the main findings, including comparisons to additional simulations. Section 4 concludes. 


\section{The Model}

\subsection{Household Optimization Problem}

We develop a dynamic discrete-time model of household grain management. Each period is a cropping season, so that the focus is on inter-seasonal consumption-smoothing rather than intra-seasonal smoothing. Consider a household whose utility each period depends on consumption of two goods -- grain $\left(x_{\mathrm{t}}^{\mathrm{g}}\right)$ and a generic good bought in the market $\left(x_{\mathrm{t}}^{\mathrm{m}}\right)$. The household has a fixed resource $z$ (e.g., land) that is allocated each period between grain production $\left(z_{t}^{g}\right)$ and cash cropping $\left(z_{t}^{c}\right)$. Output of grain $\left(g_{t}\right)$ and the cash crop $\left(c_{t}\right)$ depends on the amount of resources allocated and the realization of a random multiplicative production shock $\left(\theta_{\mathrm{t}}\right)$. Supply responses occur only by substitution of fixed resources; there is no varying the intensity of cultivation. The household also can save between periods in the form of bonds $\left(b_{t}\right)$ which earn interest $r$ or grain storage $\left(s_{t}\right)$ which spoils at rate $\psi^{h}$. Bonds can represent any competing assets with relatively constant returns, especially financial assets such as cash holdings, savings deposits, or informal lending. The household can purchase and sell grain $\left(g p_{\mathrm{t}}\right.$ and $\left.g s_{\mathrm{t}}\right)$ at a market price $\left(p_{\mathrm{t}}\right)$ but must bear a transaction cost $(\tau)$. The price of the cash crop is assumed constant and normalized to 1 . The assumption that cash crop price is not affected by aggregate shocks is justified by the greater market integration of commercial crops.

Cash crop and grain sales plus previous savings in the form of bonds permit expenditures on the marketed good. As is standard for precautionary savings models, the household is assumed to be credit constrained, an assumption which I later relax. It can borrow neither grain nor money, so that $s_{\mathrm{t}}$ and $b_{\mathrm{t}}$ must be non-negative. The grain price each period and expectations for future grain prices depend on dynamically consistent aggregate production and storage decisions and aggregate production shocks formalized in a separate market model. The household makes consumption, production, asset choice, and marketing decisions each period to maximize 
expected utility. The infinitely-lived household's full optimization problem can be expressed as follows:

$$
\begin{aligned}
& \text { Maximize } E U_{0}=E_{0}\left[\sum_{t=t_{0}}^{\infty} \beta^{t-t_{0}} \frac{\left(x_{t}^{g^{\gamma}} x_{t}^{m}\right)^{1-R}}{1-R}\right] \\
& \text { s. t. } \\
& g_{t}=z_{t}^{g}\left(1+\theta_{t}\right) \quad \text { (grain production), } \\
& \mathrm{c}_{\mathrm{t}}=\mathrm{cz}_{\mathrm{t}}^{\mathrm{c}}\left(1+\theta_{\mathrm{t}}\right) \text { (cash crop production), } \\
& \theta_{t}=\alpha_{1} \theta_{t}^{i}+\alpha_{2} \theta_{t}^{a} \quad \text { (yield shock), } \\
& Z_{t}^{g}+Z_{t}^{c}=Z \quad \text { (resource constraint), } \\
& c_{t}(1-\tau)+b_{t-1}(1+r)+p_{t}(1-\tau) g s_{t}=x_{t}^{m}+b_{t}+p_{t}(1+\tau) g p_{t} \quad \text { (budget constraint), } \\
& g_{t}+s_{t-1}\left(1-\psi^{h}\right)+g p_{t}=x_{t}^{g}+s_{t}+g s_{t} \quad \text { (grain balance), } \\
& s_{t} \geq 0 \text { and } b_{t} \geq 0 \text { (non-negativity), and } \\
& s_{0}=\underline{s} \text { and } b_{0}=\underline{b} \text { (initial conditions). }
\end{aligned}
$$

Utility is assumed to be time separable and to exhibit constant relative risk aversion.

Preferences are fully described by three parameters: $\gamma$, which determines expenditure shares for grain and the marketed good; $R$, relative risk aversion with respect to consumption of the marketed good; and $\delta$, the rate of time preference which determines the discount factor $(\beta=$ $1 /(1+\delta))$. Relative risk aversion with respect to grain consumption is equal to $\chi(R-1)+1$.

Therefore, if $\gamma>1$ and $R>1$ as expected for poor households, then the household is more risk averse with respect to grain consumption than with respect to marketed goods consumption.

With fixed income $(I)$ and certain prices, the expenditure shares for grain and the marketed good implied by the utility function are 


$$
\frac{p^{g} x^{g}}{I}=\frac{\gamma}{1+\gamma} \text { and } \frac{p^{m} x^{m}}{I}=\frac{1}{1+\gamma}
$$

Expenditure shares are constant and income elasticities of consumption are equal to 1 for both goods. Although inconsistent with Engel's Law, this formulation permits explicit specification of risk aversion and consumption shares.

Production technology for both crops is assumed linear and subject to the same multiplicative output shock $\left(\theta_{\mathrm{t}}\right)$, which has both idiosyncratic $\left(\theta_{\mathrm{t}}^{\mathrm{i}}\right)$ and aggregate $\left(\theta_{\mathrm{t}}^{\mathrm{a}}\right)$ components. The constant returns to scale assumption implies that without risk, there is complete specialisation when the return to grain and cash crops differ. There are no complementarities (i.e., intercropping) or land heterogeneity that would naturally lead to mixed cropping. Such explanations are excluded intentionally not because they lack validity but because my goal is to assess the extent to which grain's unique properties as a consumption good can explain observed behavior. Omission of time subscripts for the production function and fixed resource reflect an assumption that resource availability and production technology are fixed, which is realistic for areas where sloped, fragmented land plots are farmed with simple agricultural techniques and there is little scope for investments in land. ${ }^{2}$ Also, although I have described the alternative activity as cash crop production, one could also consider it to be other activities such as off-farm employment.

Consumption of the marketed good and grain are limited by the household's budget constraint and grain balance equation. In the household's budget constraint each period, income each period is the sum of cash crop sales net of transaction costs $\left(c_{t}(1-\tau)\right)$, the return on bonds purchased last period $\left(b_{\mathrm{t}-1}(1+r)\right)$, and income from grain sales $\left(g \mathrm{~s}_{\mathrm{t}}\right)$ at market price $p_{\mathrm{t}}$ and with a transaction $\operatorname{cost}(\tau)$. Income is spent on purchases of the marketed good $\left(x_{t}^{\mathrm{m}}\right)$, whose price is also normalized to equal one, bonds $\left(b_{t}\right)$, and grain $\left(p_{t}(1+\tau) g p_{t}\right)$. In the grain balance equation, grain can flow into the household from own-farm production $\left(g_{\mathrm{t}}\right)$, storage carryover from last period $\left(\mathrm{s}_{\mathrm{t}}\right.$ 
1) subject to a proportional storage cost $\psi^{\mathrm{h}}$, and grain purchases $\left(g p_{t}\right)$. These must balance with grain outflows, which are composed of consumption $\left(x_{\mathrm{t}}^{\mathrm{g}}\right)$, storage in the current period $\left(s_{\mathrm{t}}\right)$, and grain sales $\left(g s_{\mathrm{t}}\right)$.

\subsection{Market Equilibrium and Price Determination}

As noted by Besley (1995), to model accumulation of specific assets satisfactorily, "one would need to supplement the savings model with one of equilibrium in the market for such assets." A separate dynamic market model generates the prices and price expectations observed by the household. An internally consistent market model is essential because other specifications, such an ARMA process for prices, allow for arbitrage opportunities that should not exist in a competitive market and which are sufficient reason for households to store grain, risk considerations aside. The linkage of the household and market models is analagous to a model of a small island trading with a larger island (Williams and Wright, 1991).

Market prices faced by households are uncertain and may be correlated with household output if yield risk has an aggregate component. This price endogeneity is captured formally by linking the aggregate component of output risk faced by the household to price determination in the market. While the household faces an output shock $\left(\theta_{\mathrm{t}}\right)$ that is the weighted sum of two independent random variables representing an idiosyncratic shock $\left(\theta_{\mathrm{t}}^{\mathrm{i}}\right)$ and an aggregate shock $\left(\theta_{\mathrm{t}}^{\mathrm{a}}\right)$, market-level supply is affected only by the aggregate shock $\left(\theta_{\mathrm{t}}^{\mathrm{a}}\right)$. The correlation between the household's total shock and the aggregate shock is a simple function of the shock weights: $\rho\left(\theta_{t}, \theta_{t}^{a}\right)=\frac{\alpha_{2}}{\alpha_{1}+\alpha_{2}}$

To accurately determine how aggregate shocks affect prices and price expectations, the grain market is modeled using a rational expectations commodity market model (Wright and Williams 1982, Williams and Wright, 1991; Miranda and Helmberger, 1988; Deaton and 
Laroque, 1992 and 1996). The equilibrium price is determined by a linear market inverse demand curve,

$$
p_{t}=d_{0}-d_{1}\left(m a_{t}-m s_{t}\right)
$$

In the demand equation, the quantity consumed each period is equal to the post-harvest market grain availability $\left(m a_{\mathrm{t}}\right)$ minus market storage held into the next period $\left(m s_{\mathrm{t}}\right)$. The sum of market storage, minus spoilage, and the stochastic realization of planned production $\left(m z_{t+1}\right)$ equals the market availability at the beginning of the next period:

$$
m a_{t+1}=m s_{t}\left(1-\psi^{m}\right)+m z_{t+1}\left(1+\theta_{t}^{a}\right)
$$

Production is determined by a linear supply curve in which the sown area to grain $\left(m z_{t+1}\right)$ is a positive function of the producer incentive price $\left(p_{t+1}^{\mathrm{r}}\right)$, the expected future price weighted by output shock realizations:

$$
m z_{t+1}=s_{0}+s_{1} p_{t+1}^{r} \text { and } p_{t+1}^{r}=E_{t}\left[\left(1+\theta_{t+1}^{a}\right) p_{t+1}\right]
$$

By the Second Welfare Theorem, the competitive equilibrium of the market model is identical to the solution of a social planner's problem. The planner's first-order condition for maximizing the sum of consumer and producer surplus yields an intuitive storage arbitrage condition:

$$
p_{t}\left(m a_{t}-m s_{t}\right)-\frac{1-\psi^{m}}{1+r} E_{t}\left[p_{t+1} \mid m s_{t}\right]=0 \text { if } m s_{\mathrm{t}}>0 \quad\left(>0 \text { if } m s_{\mathrm{t}}=0\right)
$$

This condition implies that when market storage is positive, the expected price next period is proportional to the current price and the expected return to grain storage equals the interest rate. When market storage is zero, expected price next period does not cover the cost of storage. These conditions define a market equilibrium in the face of stochastic shocks. Market grain spoilage is assumed to be less than the individual spoilage rate while the interest rate is assumed to be equal to the rate of return on bonds held by households. This means that the expected return to household grain storage is always less than the return to the other asset (bonds). For internal consistency, storage and production decisions must imply expected future prices that make the 
returns to storage cover its costs (storage arbitrage condition) and that provide incentives sufficient to elicit the amount produced (supply equation).

\subsection{Stochastic Dynamic Programming Problem}

In each period the household observes a starting availability of grain $\left(a_{\mathrm{t}}\right)$ and financial wealth $\left(w_{\mathrm{t}}\right)$ and faces a market price $\left(p_{\mathrm{t}}\right)$, where $a_{\mathrm{t}}$ and $w_{\mathrm{t}}$ are defined by the identities:

$$
a_{t}=g_{t}+s_{t-1}\left(1-\psi^{h}\right) \text { and } w_{t}=c_{t}+b_{t-1}(1+r) \text {. }
$$

Grain availability is the sum of realized grain output and carryover grain stocks from the previous period. Financial wealth is the sum of cash crop income and the value of bonds held from the previous period. The household simultaneously makes four control decisions: purchase or sell grain, divide available grain net of market transactions between consumption and storage, divide available financial wealth between purchases of the marketed good and bonds, and allocate the fixed resource between grain and cash crop production to be harvested next period. It makes these decisions with the knowledge that the yield and price next-period are uncertain, but may be correlated. The asset choice and production decisions then determine next period grain availability and financial wealth, subject to a production shock. Figure 1 displays the timeline of state realizations and control decisions for the dynamic model.

Bellman's Principle of Optimality makes it possible to transform this problem into a dynamic programming problem. The three state variables fully define the information set available to the household at the start of each period. The household's strategy involves decisions about five variables: $s, b, z^{\mathrm{g}}, g s$, and $g p$. Decision rules are stationary so time subscripts are dropped. Use of the constraints and identities to express the value function as a function of current states and controls yields the following maximization problem:

$$
\underset{s, b, z^{g}, g s, g p}{\operatorname{Max}} V(a, w, p)=U(a-s+g p-g s, w-b+p(g s(1-\tau)-g p(1+r)))
$$




$$
+\beta E\left[V\left(s\left(1-\psi^{h}\right)+g\left(z^{g}, \alpha_{1} \theta^{i}+\alpha_{2} \theta^{a}\right), b(1+r)+c\left(z-z^{g}, \alpha_{1} \theta^{i}+\alpha_{2} \theta^{a}\right), p^{*}\left(p, \theta^{a}\right)\right)\right]
$$

$$
\text { s.t. } \mathrm{s}, \mathrm{b}, \mathrm{gs}, \mathrm{gp} \geq 0 ; 0 \leq \mathrm{z}^{\mathrm{g}} \leq \mathrm{z} \text {. }
$$

$\mathrm{p}^{*}$ is the expected price next period given the current price and the aggregate shock. Five first order conditions define optimal household decisions for storage, bond holding, grain purchases, grain sales, and grain sown area. The equation for each first order condition, which is presented in appendix 1, becomes an inequality when non-negativity constraints bind, or in the case of grain sown area, when the land constraint binds.

To solve this multidimensional, nonlinear problem, I extend a solution algorithm employed by Williams and Wright (1991) and follow many of the computational techniques suggested in the projection methods of Judd $(1992,1998)$. The key innovation is to avoid approximation of kinked policy or value functions that arise naturally with inequality constraints, e.g., non-negativity of storage or bonds, by reframing the problem in a way that can be solved by approximating smooth functions. ${ }^{3}$ The algorithm iterates on expected marginal value functions defined with respect to the dynamic control variables, $s_{\mathrm{t}}$ and $b_{\mathrm{t}}$, which appear in the first two firstorder conditions. In general, functions that are expectations should be smooth because they are integrals (or weighted sums) defined over all possible stochastic realizations. Recent work in computational economics has demonstrated the superior performance of this type of "parameterized expectation algorithm" (Christiano and Fisher, 2000)

The marginal expected value functions with respect to the first and second elements of the value function $\left(a_{\mathrm{t}}\right.$ and $\left.w_{\mathrm{t}}\right)$ are approximated by Chebyshev polynomials which are functions of $s_{\mathrm{t}}, b_{\mathrm{t}}$, and $m s_{\mathrm{t}}$. These can be expressed as follows:

$$
E_{t}\left[V_{t+1}^{a} \mid s_{t}, b_{t}, m s_{t}\right]=\varphi_{a}\left(s_{t}, b_{t}, m s_{t}\right) \text { and } E_{t}\left[V_{t+1}^{w} \mid s_{t}, b_{t}, m s_{t}\right]=\varphi_{w}\left(s_{t}, b_{t}, m s_{t}\right)
$$

Since marginal values will vary with the amount of grain and financial wealth available, as well as the price of grain, the expected marginal values are a function of the amount of grain and bonds stored for the next period as well as the market carryover stocks that affect next period's 
market grain availability and price. Individual and market production decisions also determine the level of next period's state variables, but optimal production is defined uniquely by the asset carryover decisions.

Given values for the state variables and initial guesses for the parameter values of the two polynomials, it is possible to solve for optimal grain production, storage, bond holding, and trade by numerically solving the system of simultaneous equations defined by the first order conditions. For each combination of starting state variables, it is then possible to compute all optimal controls that determine current utility and marginal utility. But this period's starting states are the result of control decisions made last period. And by an envelope condition, this period's marginal utility is equivalent to this period's marginal value function. Thus, for different control decisions last period and knowledge of the distribution of aggregate and idiosyncratic output shocks, one can calculate the current period state variables and marginal utilities associated with each possible realization and thus estimate values of the expected marginal value function as a function of last period's controls. This suggests an iterative algorithm in which guesses for the expected marginal value functions are replaced by new Chebyshev polynomial approximations fitted to estimated values of the previous period marginal value functions. The algorithm is described fully in appendix 1 .

\section{Household Grain Management in China}

\subsection{Grain Storage, Production, and Trade}

To make the model as realistic as possible, parameters are chosen to reflect the economic environment faced by households in Northwest China, an area where grain production and storage appear to play an important role in smoothing incomes and consumption. In

collabouration with the Rural Development Institute of the Chinese Academy of Social Sciences, I conducted extensive interviews with farmers, local officials, and grain traders in four poor, 
mountainous counties in Shaanxi Province. The survey included 288 households in 24 villages interviewed in two rounds of data collection in 1993.

Perhaps the most striking characteristic of household behavior in the study area is the large amount of grain stored on farm between harvest seasons. For the poorest quartile of households, grain stocks held just prior to the fall harvest constitute $37 \%$ of wealth apart from housing (22\% including housing), exceeding that of consumer durables, livestock, and agricultural equipment. ${ }^{4}$ For the whole sample, grain stocks comprise $31 \%$ of wealth apart from housing. Data from China's national household surveys suggest that the high levels of grain storage observed in the study area characterize much of northwest and northeast China (Crook, 1999).

According to the household survey data, interseasonal, or pre-harvest, grain storage levels on average are equivalent to $64 \%$ of annual grain production and over half a year's consumption. Grain borrowing, lending, and gift-giving constitute less than $10 \%$ of production. Grain purchases average $25 \%$ of production or about $20 \%$ of consumption, far exceeding sales, which are less than $3 \%$ of production. These data suggest that own storage is more important than risk sharing across individuals in sustaining household grain consumption in times of shortfall, consistent with empirical estimation results that show that changes in grain stocks respond to yield shocks but that lending and gift-giving do not (Park, 1998).

The share of resources devoted to grain production is also high among households in the study area. Although land and labour return to soybean cultivation were $50 \%$ more than for grain, ${ }^{5}$ about $70 \%$ of both land and labour are devoted to grain crops. There are many possible explanations for this outcome, including complementary technologies (e.g., intercropping), credit or other input constraints, and income risk diversification. However, interviewed farmers frequently cited the need to meet their own grain consumption needs. 


\subsection{Production and Marketing Environment}

Northern China has a long history of vulnerability to water shortage, yield variability, and famine. Yield risk faced by households has both aggregate and idiosyncratic components. To investigate their relative importance, total output shocks for the fall 1992 and summer 1993 harvests were decomposed into county (aggregate) and household (idiosyncratic) shocks based on the share of sown area affected by disaster (e.g., drought, flood, animal or insect infestation) based on household self-reporting by plot. For each county in each season, I first calculate the mean share of sown area affected by disaster. County shocks are the difference between these means and the means for those households who subjectively rate the harvest as "average" in that season. These ratings come from a separate question that asks household heads to rate the harvest in comparison to a typical harvest. Possible responses are excellent, good, average, poor, and very poor. Household shocks are the difference between the household share of area affected by disaster and the county mean disaster share. Although both types of shock are significant, idiosyncratic shocks, with an average magnitude of 0.25 for fall 1992 and 0.26 for summer 1993 , are slightly larger than county shocks, whose absolute value averaged 0.15 and 0.20 in the same seasons. Still, in both seasons there remains a significant correlation of 0.47 between the total shock hitting households and the aggregate shock.

The variability of aggregate production shocks is measured by analyzing data on grain yield for all counties in Shaanxi Province for the period 1980-1992. Officially designated poor counties, which tend to be located in remote, more mountainous regions, face much greater yield risk than nonpoor counties. The coefficients of variation for grain yield are twice as great for poor counties, measuring 0.13 compared to 0.06 for nonpoor counties.

In isolated markets, price determination occurs locally. Within a smaller geographic range, the individual yield realizations that comprise aggregate supply are more likely to be correlated; hence, household shocks correlate negatively with market price realizations. 
Interviews with local leaders and farmers revealed a sharp awareness of such correlation. According to time series data from 1983 to 1991 for three counties from different poor prefectures in Shaanxi, the correlation between detrended grain (wheat and corn) production variability and real prices averaged $-0.39 .{ }^{6}$ For soybeans, the average correlation is -0.06 , reflecting the greater market integration for that commodity. Additional evidence of local price determination is the large spatial price differences observed among different parts of the province, which reach as high as $70 \%$ to $100 \%$ for some crops in some years. Village average prices for 1992-93 varied within a range of $20 \%$ to $25 \%$.

High transaction costs for buying and selling grain on the local market, typically a township periodic market, also has an important effect on household production and asset choice decisions (Jayne, 1994). One component of this cost is the labour opportunity cost of marketing, which when valued at the village agricultural wage rate averages $4 \%$ of the transaction value of grain. This transaction cost is calculated from village agricultural wage data and household data on price, quantity, and time spent marketing for each grain transaction from October 1992 to August 1993. A second cost component is the margin demanded by local traders to cover their costs of providing liquidity to the market. Half the bid-ask spread of local grain stations based on data from village surveys equals $2 \%$ to $5 \%$ of the crop's value, depending on the crop. This implies an average household grain transaction cost of about $8 \%$.

\subsection{Model Parameters}

Household parameter values for the base case model are chosen to reflect the actual situation of households in northwest China and are summarized in Table 1. The parameter values for $R$ and $\gamma$ imply relative risk aversion levels of 4.00 and 3.00 with respect to consumption of grain and marketed goods. These are in the range of risk aversion reported elsewhere for households in developing countries. ${ }^{7}$ The chosen consumption share parameter implies a fixed 
expenditure share for grain of $60 \%$, close to the average of $57 \%$ of rural household living expenditures spent on food in Shaanxi in 1992 (State Statistical Bureau, 1993). ${ }^{8}$ The interest rate of $8 \%$ lies between the interest rate offered by local credit cooperatives and moneylenders. ${ }^{9}$ The rate of time preference is assumed slightly higher at $10 \%$.

The model posits an expected yield to cash crops that is $20 \%$ higher than the expected yield of grain cultivation. ${ }^{10}$ The weights on the idiosyncratic and aggregate shocks $\left(a_{1}\right.$ and $\left.a_{2}\right)$ are 1.2 and 1, reflecting the greater importance of idiosyncratic shocks. These weights imply a correlation between household and aggregate shock of 0.45 , virtually identical to the 0.47 correlation between household and county disaster-affected area. Aggregate yield variability is calibrated to reproduce the coefficient of variation of county grain yield of 0.13 . Aggregate and idiosyncratic shocks are discretized into three-point symmetric probability distributions.

The proportional cost of household grain storage, not including the interest cost of holding grain, is set to $3 \%$ which is the average spoilage rate reported by households. This rate is greater than the $1 \%$ cost of storage specified for the marketplace, where grain warehouses run by state grain traders allow for better bulk storage and treatment of grain. All grain would be stored in these warehouses were it not for transport and other transaction costs. The market transaction cost is set to $8 \%$ of price, based on the household data reported earlier. The cash crop price and average grain price are normalized to one. Coefficients for the linear inverse market demand and market supply curves imply demand and supply elasticities of -0.2 and 0.5 at the market equilibrium. $^{11}$

\section{Results}

\subsection{Characterizing Grain Management Behavior}

Before examining household risk-coping behavior, I first consider how households behave in a world of certainty. If grain yields are fixed to their mean values in both the household 
and market models, there is no market storage and a recurring market equilibrium obtains in which the price of grain is equal to one, the same as the cash crop price. The household specializes completely in cash crop production. The $20 \%$ higher return makes cash crop cultivation more profitable even when the $8 \%$ transaction cost is subtracted from the cash crop price and added to the grain price, the appropriate comparison for a grain purchaser. Thus, even with a positive transaction cost and a $60 \%$ expenditure share for grain, it makes sense for the household to grow cash crops and purchase grain for consumption--to be fully commercialized. If the grain price plus the transaction cost were greater than the cash crop price minus the transaction cost, the household would produce enough grain to meet its consumption needs and neither purchase or sell grain. If the grain price were higher than the cash crop price, the household would fully specialize in grain and sell grain on the market. With certainty and a fixed amount of productive resources each period, there is no asset holding in the long run equilibrium. Given different initial grain availability and financial wealth, the household may hold assets to spread consumption into the future. But since the rate of time preference is greater than the interest rate, the household prefers consumption earlier rather than later and so will quickly draw down initial assets to zero, and approach the long run equilibrium in which no assets are held.

Once uncertainty is added, the household's problem becomes more complicated. Production and asset choice decisions balance the household's desire to maximize profits, on the one hand, and reduce consumption risk exposure, on the other. These strategies frequently deviate from those based on profit maximization, or even those of a risk-averse producer. Figures 2 and 3 trace out price response functions for asset choice, production, and trade decisions when the household confronts low and high levels of grain availability and wealth. These situations correspond roughly with scenarios in which the household has had a string of poor harvests and a string of good harvests, respectively. Economists are accustomed to thinking of household agricultural supply and marketing as smooth, even linear functions of prices or expected prices, 
i.e., the conventional supply curve. ${ }^{12}$ Here, household decisions are highly nonlinear and depend not only on market conditions but also on the grain availability and financial wealth of the household.

With low levels of starting grain availability and financial wealth, the household's strategy is straightforward (Figure 2). No grain storage or bonds are held over to the next period because the household is facing a subsistence crisis. The household realizes that with no savings it could face difficulties in feeding itself if the harvest were poor and the price went up next period. The household thus plants more grain as a consumption price hedge. Even at low prices (below 0.85 ) at which grain is much less profitable than the cash crop, the household plants grain. ${ }^{13}$ As the current grain price increases (and with it the expected price next period), the household plants more grain, up to about $70 \%$ of land. Beyond that, it is concerned about being exposed to downward price risk in converting grain to cash to purchase the marketed good. The household purchases some grain to meet the desired expenditure shares for grain and the marketed good, and as the price increases the amount of grain purchased declines.

At high levels of grain availability and financial wealth, the household holds assets to smooth consumption into future periods (Figure 3). Its grain storage decision is nonlinear with respect to price. At low price levels, the expected grain price next period is also low because of market carryover stocks, reducing the price risk perceived by farmers. Households prefer to hold bonds which earn a higher return. At high price levels, households also become reluctant to store grain. First, grain production becomes more attractive, so the household does not need to rely as much on storage to hedge against consumption risk. Second, above a threshold price, the market stocks out of grain and the market storage arbitrage condition no longer holds, reducing the expected asset return to grain storage. It is only at intermediate prices that grain is stored in large amounts, peaking at a level equal to a full year's consumption. The pattern of bond holding is the inverse of grain storage with respect to the grain price. The supply curve is different when the 
household has high levels of grain availability and wealth (Figure 3, solid line). The price at which the household is first willing to plant grain is $10 \%$ higher than in the case of low grain availability and financial wealth (Figure 2), since its precautionary savings reduce its risk exposure next period. At high prices, the household is more willing to specialize fully in grain production. In other words, with higher grain availability and financial wealth, supply response is more price elastic. The relationship between grain trade and price is also nonlinear and is influenced by the household's asset choice strategy (Figure 3, bottom line). Net purchases are higher when the household is storing grain. There is even a price range $(0.77-0.83)$ for which purchases increase with higher prices because the household is building up stocks as a price hedge. This may provide an alternative explanation to speculative hoarding when households are observed to hold more grain as prices rise.

I simulate a household's life through 1000 harvest periods using the base-case parameterization. The household each period behaves according to the policy rules just described, reacting to current grain availability, financial wealth, and market conditions. All simulations are based on random realizations of production uncertainty each period. The household and market start with no assets carried over into the initial period. Summary statistics for different household decision variables and market outcomes are presented in Table 2. The ratio of average grain consumption and average marketed goods consumption is $6: 4$ as parameterized.

Mean grain storage averages 24 , equal to $36 \%$ of average grain consumption. Average bond holding is 30 . Combined with grain, the value of precautionary savings on average is sizable, equal to approximately half of average realized income. ${ }^{14}$ In $38 \%$ of periods, the household holds zero grain stocks and in $19 \%$ of periods is without bonds. The average amount of grain storage is somewhat below the $50 \%$ of consumption observed in Shaanxi. This difference could reflect the fact the simulation mean is for a representative household over time, while the sample mean is the cross-sectional average across heterogenous households experiencing 
different shocks at a single point in time. Nonetheless, if risk is discretized to allow for lower probability, larger negative shocks, mean grain storage increases substantially (see appendix 2). In the base case, both aggregate and idiosyncratic risk are approximated by symmetric three-point probability distributions. The maximum negative shock is $37 \%$. If instead I allow the distribution to be asymmetric and include a negative shock of $88 \%$ while maintaining the same coefficient of variation, ${ }^{15}$ behavior changes markedly. Most notable is the almost doubling of average grain stocks, from 24 to 43 , or over $60 \%$ of consumption. Average grain sown area, on the other hand, falls from 38 to 30 . Production is a less effective risk hedge because of the greater volatility in yield realizations and strong link between negative aggregate yield shocks and high market prices. Thus, small probability events can have a large effect on behavior, a point that is particularly salient for the Chinese case given memories of famine during the Great Leap Forward during 1959-61.

The household on average allocates $38 \%$ of its productive resources (e.g., land) to grain cultivation. In $42 \%$ of the periods, however, it grows no grain at all, fully specializing in the cash crop. The fact that fully specialized households are not often observed in practice could be accounted for by complementarities to production, input constraints, or imperfect yield correlation across crops--features that have been intentionally excluded from the model.

The household is usually a purchaser but rarely a seller of grain, buying grain in $66 \%$ of the periods and selling grain in only $14 \%$ of periods. On average, net purchases of grain equal $44 \%$ of consumed grain and $72 \%$ of produced grain. These amounts are much higher than in the household data. This result is likely a byproduct of the model's underestimation of grain production. Gross sales are negligible, just as in the household data.

The results in Table 2 illustrate that the household's grain management strategy helps it to smooth consumption. The coefficients of variation for yield and price are 0.20 and 0.24 respectively, but the coefficients of variation for consumption of the marketed good and grain are 
0.11 and 0.17 , respectively. To achieve this stabilization, however, the household adjusts its strategy considerably from period to period, as seen in the very high variability of grain storage, bonds, grain purchases and sales, and area sown to grain. To see how average behavior changes when different assumptions are made about preferences, technology, and market demand and supply elasticities, I alter the relevant model parameters, re-solve the model, and run new simulations. The sensitivity analysis results are summarized in appendix 2 .

\subsection{Risk, Saving, and Credit}

This study is the first to model the asset composition of precautionary savings in a way that captures grain's unique consumption price-hedging properties, which explains why rural households in developing countries hold substantial grain stocks despite lower rates of return in comparison to other assets. Figure 3 shows that household asset choices are non-monotonic with respect to price, and are made jointly with household production decisions. Next, we extend the model to consider how these choices depend upon assumptions about the credit market.

Previous models of precautionary savings generally assume that households are credit constrained (Deaton, 1990). To test the effect of relaxing credit constraints, a simulation is run in which the household is allowed to hold a negative amount of bonds. This allows the household to borrow up to a fixed amount at the same interest rate it receives on savings deposits. A common expectation is that with access to credit, the household will reduce its precautionary savings. Here, the compositional effects are of greater interest. In the simulations with credit, average bond holding falls by a magnitude approximately equal to the amount of credit permitted, but the average amount of grain storage changes very little (Table 3). Grain storage is not held in lieu of credit, but rather as a price hedge. Improving rural credit access is not likely to lead farmers to substantially reduce precautionary grain storage. 
To emphasize the importance of price hedging in motivating grain storage, we conduct a simulation for the case in which there is no price risk (Table 3). This differs from the certainty case because we maintain yield risk. Because grain and cash crop yields are perfectly correlated, there is no income portfolio diversification motive to produce grain. With constant relative price and perfectly correlated yields, the household maximizes return in both the production and saving decisions, planting all land to the cash crop and holding all wealth in the form of bonds.

It is straightforward to prove why absent price risk, production and storage of grain will disappear. First consider the production decision. Suppose the household plants some land to grain $\left(z_{t}^{g}>0\right)$. Given previous period storage $\left(s_{t-1}\right)$ and bond holding decisions $\left(b_{t-1}\right)$, postharvest grain availability and wealth can be expressed as follows:

$$
a_{t}=z_{t}^{g}\left(1+\theta_{t}\right)+s_{t-1}\left(1-\psi^{h}\right) \text {, and } w_{t}=c\left(z-z_{t}^{g}\right)\left(1+\theta_{t}\right)+b_{t-1}(1+r) \text {. }
$$

Next, consider an alternative strategy of specializing in cash crop production. To facilitate comparisons to the case with grain production, we calculate the amount of grain that would be available if the household purchased as much grain as possible post harvest while maintaining the same amount of financial wealth as in the former case. In this case, grain availability would be the following:

$$
a_{t}^{\prime}=s_{t-1}\left(1-\psi^{h}\right)+\frac{C z_{t}^{g}\left(1+\theta_{t}\right)}{1+\tau} .
$$

Comparing grain availability in the two cases, $a_{t}^{\prime}>a_{t}$ if $\frac{c}{1+\tau}>1$, which is true for the baseline parameters $(\mathrm{c}=1.2, \tau=0.08)$. Thus, specializing in cash crop production is always a dominant strategy.

The absence of grain storage can be proven in analogous fashion. To see this clearly, consider grain availability and wealth when storage is positive and the household specializes in cash crops: 


$$
a_{t}=s_{t-1}(1-\psi) \text { and } w_{t}=c z\left(1+\theta_{t}\right)+b_{t-1}(1+r)
$$

Now consider an alternative asset portfolio in which grain storage is zero. Assuming that stored grain was purchased, bondholding in this case is $b_{t-1}^{\prime}=b_{t-1}+s_{t-1}(1+\tau)$. Following the previous approach, if the household purchases as much grain as possible post-harvest while maintaining the same amount of wealth as in the former case, grain availability is $a_{t}^{\prime}=s_{t-1}(1+r)$. Comparing this to the case with positive grain storage reveals that zero grain storage is a dominant strategy. This confirms the intuition that without price risk, the household will hold assets with the highest rate of return. ${ }^{16}$

\subsection{Risk and Production}

The policy rules described above show that the willingness to plant grain depends on the market price as well as the household's financial wealth and grain availability. Other studies have shown that ex ante income-smoothing strategies, such as planting crops with lower return and less yield risk or crop diversification, may depend on ex-post consumption-smoothing ability, such as through credit or insurance (Morduch, 1990; Eswaran and Kotwal, 1989). Here, we make a related but different argument. Production decisions respond to risk not to reduce income variability but to reduce consumption variability (Fafchamps, 1992). Like storage, production is used to hedge against consumption price risk. Given the joint nature of asset choice and production decisions, household grain production depends not just on wealth, but also the type of assets held.

To see this more clearly, I compare the base case simulation results to the case in which households are unable to hold any assets to smooth consumption across periods, so that the only possible ex ante adjustment for risk considerations is the production decision. The parameterization of the no asset model is otherwise identical to the base case scenario. With no assets, the household repeatedly solves a single-period production under uncertainty problem that 
has been extensively studied. ${ }^{17}$ As seen in Table 3, mean grain production increases from 39 in the base case to 48 in the no asset case, a jump of nearly $20 \%$. Average income and consumption levels are lower in the no asset case, reflecting sacrifices made to reduce risk exposure. The inability to save thus reduces the efficiency of production decisions, also leading to less purchases and more sales of grain on average.

A no asset model thus over-predicts the extent to which production decisions respond to risk (Morduch, 1990). This finding has important implications for poverty dynamics. To measure the extent to which risk affects resource allocation decisions, for each period in the base case simulations, I calculate the difference between expected production income if the household maximizes expected profits rather than expected utility. The determination of profit-maximizing sown area decisions (and expected income) is complicated by the fact that with positive transaction costs, the expected farm-gate value of grain production will depend on the expected marketing status of the household (seller, purchaser, autarky), which itself depends on the household's production decision. ${ }^{18}$ When we compare expected income from profit-maximizing planting decisions and utility-maximizing planting decisions, the difference is less than $2 \%$ of expected income on average (Table 4). This compares to $6 \%$ in the no asset case. Changing assumptions about preferences or the relative returns to cash crop and grain production do not greatly alter the magnitudes of the income loss. ${ }^{19}$

An important reason for low differences in expected profits is that the ability of households to hold precautionary savings as a risk hedge makes them much less willing to make production decisions for which expected returns fall significantly below profit-maximizing returns. Income losses are low despite the fact that the average difference between utilitymaximizing and profit-maximizing levels of grain sown area is substantial, averaging $23 \%$ of total sown area. A similar contrast between small efficiency losses and large behavioral responses also characterizes policy simulations using computable general equilibrium models (Srinivasan 
and Whalley, 1986; Devarajan, Lewis, and Robinson, 1990). These results suggest that we should be cautious in drawing implications about income effects from empirical research that finds a large behavioral responses to uncertainty.

\subsection{Risk and Marketing}

In low income environments characterized by subsistence farming, few households are large net sellers of grain, while purchases of grain are much more common. As described earlier, this is true of the farm households surveyed in northwest China. Using nonparametric methods, Barrett and Dorosh (1996) find that in low-income rice-producing areas in Madagascar in 1990, $60 \%$ of households made rice purchases, and only $5 \%$ of rice-farming households accounted for $50 \%$ of rice sales, which were a very small share of expenditures on average. Budd (1993) uses similar methods to show that in the Ivory Coast in 1995 farmers were not self-sufficient and few were net sellers. In general, they "grow crops to consume and only sell the crop when prices are especially good."

Earlier we described how, under certainty, households either fully specialize in grain or the cash crop, or produce exactly what they plan to consume if transaction costs make selfsufficiency optimal. This leaves little room for subsistence households to be net purchasers or sellers. Even if the expenditure share of grain is higher for the poor, poor households should simply grow more grain, not purchase grain. Of course, if poor households face a binding consumption constraint that prevents them from meeting minimum consumption needs, net purchases may be unavoidable. However, at low income levels, the expenditure share of food is usually observed to be relatively constant rather than declining as implied by a subsistence constraint assumption (see Budd (1993) for a review). The model's utility function assumes a constant food expenditure share, so rules out explanations for marketing behavior related to differences in relative expenditure requirements. 
Uncertainty itself may be a more natural explanation for the variation in market participation across households in any given year. In the baseline simulations, the household purchases grain in $66 \%$ of periods and sells grain in only $14 \%$ of periods, neatly capturing the stylized facts (Table 2). The reason for this behavior is related to the inherent risk of production, the non-negativity of storage, and the consumption price-hedging motive for storing grain. When the household has stocked out of grain, it has no choice but to purchase grain to meet consumption demand, but if there is a large surplus, the household can store it for price-hedging purposes rather than sell it. This is particularly true in isolated markets with negative yield-price correlations. Unexpected surpluses result from positive yield shocks which are usually associated with a lower market price. The lower market price makes sales less attractive, makes planting grain less attractive, and usually means that expected future prices nearly cover the opportunity costs of storage. All of these factors make grain storage a more attractive option, explaining the low propensity to sell surplus grain. Farmer's have internalized this logic, instinctively storing surplus grain and selling only to meet specific cash expenditure requirements. Barrett and Dorosh (1996) also find that at higher income levels, households increasingly stored rather than sold rice surpluses. Households even stored grain from a negative marketable surplus position.

This explanation for observed marketing behavior of subsistence farmers suggests that the cross-sectional positive association between income level and marketed surplus observed in many countries may reflect variation in realized shocks across households rather than systematic differences associated with household characteristics. This distinction may have important policy implications. For example, stabilization policies may be more valuable than policies targeting the chronic poor. Analyses of the welfare effects of food price changes on different income groups using cross-sectional data may lead to misleading conclusions.

\section{Conclusions}


Rural households in many parts of the developing world live in environments in which agricultural yields are highly variable and markets underdeveloped. Grain buffer stocks have been shown to be an important consumption smoothing asset in developing countries throughout the world and many farmers prefer to grow the crops that they consume rather than rely on the market. The dynamic model of household grain management developed in this paper has been the first to include all key aspects of household decision-making--production, savings, trade, and consumption; allow for both price and yield uncertainty; and explicitly model the market for grain. Parameterized to Chinese data, the model has shown that households choose grain management strategies that balance the goal of maximizing income with the desire to hedge against consumption price risk. Model simulations have shown that the jointness of production, storage, and trade decisions is important. These decisions are not made in isolation of each other but rather form a coordinated strategy.

The model simulation results provide new insights into how household asset choices, production decisions, and marketing decisions respond to risk. First, the model for the first time analyzes the composition of precautionary saving by carefully modeling the characteristics of a specific asset - grain. Because of the price hedging motive for holding an asset that is consumed, precautionary savings in the form of grain are not the result of credit constraints and will persist even if the household has access to credit. This suggests that attempts to reduce precautionary grain storage, which have high opportunity costs for the household and the economy, by improving credit access for the poor will be ineffective and price stabilization policies hold greater promise.

Second, the model results show that production response to risk depends not just on wealth, taken as a proxy for the ability to smooth consumption ex-post, but also on the types of assets held, in particular grain, since different assets have different consumption-smoothing ability when prices are uncertain. The ability to hold assets affects the need and willingness of 
households to distort production decisions to smooth income. In model simulations, the multiplicity of risk-coping mechanisms leads to a very modest expected income loss associated with risk-coping. Thus, this analysis casts an optimistic light on the ability of rural households to cope with risk, downplaying the need for policies to make production decisions more efficient and less influenced by risk considerations.

Finally, the model results explain the observed behavior in poor, rural areas that subsistence households are often net purchasers of grain and rarely sell grain. Yield risk, the nonnegativity of storage, the risk-hedging properties of grain, and the negative yield-price correlation found in remote areas all play a role in explaining this behavior. The results suggest that pricing policies may have a limited ability to increase marketed surpluses unless they integrate markets, reduce price risk, or make grain production commercially viable. Simple inferences about the welfare effects based on whether households are net sellers or net purchasers may be misleading. 


\section{References}

Barrett, C. and Dorosh, P. (1996). 'Farmers' welfare and changing food prices: nonparametric evidence from rice in Madagascar', American Journal of Agricultural Economics, vol. 78, pp. 656-69.

Besley, T. (1995). 'Savings, credit and insurance', in (J. Behrman and T. Srinivasan, eds.), Handbook of Development Economics, Volume III, Amsterdam: North Holland.

Binswanger, H. (1980). 'Attitudes toward risk: experimental measurement in rural India', American Journal of Agricultural Economics, vol. 62, pp. 395-407.

Binswanger, H. and Rosenzweig, M. (1993). 'Wealth, weather risk and the composition and profitability of agricultural investments', ECONOMIC JOURNAL, vol. 103, pp. 56-78.

Budd, J. (1993). 'Changing food prices and rural welfare: a nonparametric examination of the Cote d'Ivoire', Economic Development and Cultural Change, vol. 41, pp. 587-603.

Caballero, R. (1991). 'Earnings uncertainty and aggregate wealth accumulation', American Economic Review, vol. 81, pp. 859-71.

Carroll, C. (1994). 'How does future income affect current consumption?', The Quarterly Journal of Economics, vol. 109, pp. 111-47.

Carter, M. and Zimmerman, F. (2000). 'The dynamic cost and persistence of asset inequality in an agrarian economy', Journal of Development Economics, vol. 63(2), pp. 265-302.

Christiano, L. and Fisher, J. (2000). 'Algorithms for solving dynamic models with occasionally binding constraints', Journal of Economic Dynamics and Control, vol. 24(8), pp. 11791232.

Crook, F. W. (1999). 'The impact of China's grain reserve system on import demand', in (C. Findlay, ed.), Food Security and Economic Reform: Challenges Facing China's Grain Marketing System, Studies on the Chinese Economy Series, New York: Macmillan.

Deaton, A. (1990). 'Saving in developing countries: theory and review', Proceedings of the World Bank Annual Conference on Development Economics 1989, Washington, D.C.: The World Bank.

Deaton, A. (1991). 'Saving and liquidity constraints', Econometrica, vol. 59, pp. 1221-1248.

Deaton, A. and Laroque, G. (1992). 'On the behavior of commodity prices,' Review of Economic Studies, vol. 59, pp. 1-23.

Devarajan, S, Lewis, J. D. and Robinson, S. (1990). 'Policy lessons from trade focused, two-sector models', Journal of Policy Modeling, vol. 12(4), pp. 625-57.

Eswaran, M. and Kotwal, A. (1993). 'Credit as insurance in agrarian economies', Journal of Development Economics, vol. 31, pp. 37-53.

Fafchamps, M. (1992). 'Cash crop production, food price volatility, and rural market integration in the third world', American Journal of Agricultural Economics, vol. 74, pp. 90-99.

Fafchamps, M. and Pender, J. (1997). 'Precautionary savings, credit constraints, and irreversible investments: evidence from semi-arid India', Journal of Business and Economic Statistics, vol. 15, pp. 180-94.

Fafchamps, M., Udry, C. and Czukas, K. (1998). 'Drought and saving in west Africa: are livestock a buffer stock?', Journal of Development Economics, vol. 55, pp. 273-305.

Finkelshtain, I. and Chalfant, J. (1991). 'Marketed surplus under risk: do peasants agree with Sandmo?', American Journal of Agricultural Economics, vol. 73, pp. 557-67.

Jayne, T.S. (1994). 'Do high food marketing costs constrain cash crop production?: evidence from Zimbabwe," Economic Development and Cultural Change, vol. 42, pp. 387-402.

Judd, K. (1992). 'Projection methods for solving aggregate growth models', Journal of Economic Theory, vol. 58, pp. 410-52.

Judd, K. (1998). Numerical Methods in Economics, Cambridge: MIT Press. 
Kochar, A. (1995). 'Explaining household vulnerability to idiosyncratic income shocks', American Economic Review, vol. 85, pp. 159-64.

Lim, Y. and Townsend, R. (1998). 'General equilibrium models of financial systems: theory and measurement in village economies', Review of Economic Dynamics, vol. 1(1), pp. 59118.

Miranda, M. and Helmberger, P. (1988). 'The effects of commodity price stabilization programs', American Economic Review, vol. 78, pp. 46-58.

Morduch, J. (1990). 'Risk, production and saving: theory and evidence from Indian households', unpublished manuscript.

Morduch, J. (1995). 'Income Smoothing and Consumption Smoothing', Journal of Economic Perspectives, vol. 9, pp. 103-14.

Park, A. (1996). Household Grain Management Under Uncertainty in China's Poor Areas, unpublished Ph.D. dissertation, Palo Alto: Stanford University.

Park, A. (1998). 'Risk, asset choices, and mutual insurance in rural China', unpublished manuscript.

Renkow, M. (1990). 'Household inventories and marketed surplus in semisubsistence agriculture', American Journal of Agricultural Economics, vol. 72, pp. 664-75.

Rosen, S. (1987). 'Dynamic animal economics', American Journal of Agricultural Economics, vol. 69, pp. 547-57.

Rosen, S., Murphy, K. and Scheinkman, J. (1994). 'Cattle cycles', Journal of Political Economy, vol. 102(3), pp. 468-92.

Rosenzweig, M. and Wolpin, K. (1993). 'Credit market constraints, consumption smoothing, and the accumulation of durable production assets in low-income countries: investments in bullocks in India', Journal of Political Economy, vol. 101, pp. 223-44.

Saha, A. (1994). 'A two-season agricultural household model of output and price uncertainty', Journal of Development Economics, vol. 45, pp. 245-69.

Saha, A. and Stroud, J. (1994). 'Household model of on-farm storage under price risk', American Journal of Agricultural Economics, vol. 76, pp. 522-34.

Sandmo, A. (1971). 'On the theory of the competitive firm under price uncertainty', American Economic Review, vol. 61, pp. 64-73.

Srinivasan, T.N. and Whalley, J. (1986). General Equilibrium Trade Policy Modeling, Cambridge: MIT Press.

State Statistical Bureau (1993). China Statistical Yearbook (zhongguo tongji nianjian) 1992, Beijing: China Statistics Press (zhongguo tongji chubanshe).

Tsakok, I. (1990). Agricultural Price Policy: A Practitioner's Guide to Partial-Equilibrium Analysis, Ithaca: Cornell University Press.

Udry. C. (1995). Risk and savings in northern Nigeria', American Economic Review, vol. 85, pp. 1287-1300.

Walker, T. and Ryan, J. (1990). Village and Household Economies in India's Semi-arid Tropics, Baltimore and London: Johns Hopkins University Press.

Williams, J. and Wright, B. D. (1991). Storage and Commodity Markets, New York: Cambridge University Press.

Wright, B. D. and Williams, J. (1982). 'The economic role of commodity storage', ECONOMIC JOURNAL, vol. 92, pp. 596-614.

Wright, B. D. and Williams, J. (1984). 'The welfare effects of the introduction of storage', Quarterly Journal of Economics, vol. 99, pp. 169-82.

Zeldes, S. (1989). 'Consumption and liquidity constraints: an empirical investigation', Journal of Political Economy, vol. 97, pp. 305-46. 
Zimmerman, F. and Carter, M. (2003). 'Asset smoothing, consumption smoothing and the reproduction of inequality under risk and subsistence constraints', Journal of Development Economics, vol. 71(2), pp. 233-60. 


\section{Appendix 1}

\section{Numerical Solution Algorithm}

The numerical algorithm is an extension of the one used to solve the basic storage and production model in Williams and Wright (1991, Chapter 3) (given in less detail in Wright and Williams (1984)). Iteration over marginal expected value functions rather than value functions or policy rules is the innovation common to these algorithms.

To deal with the greater complexity and higher dimensionality of the household problem, recent techniques in computational methods have been employed, following the suggestions of Judd (1998). The algorithm can be mapped into the general projection methods for solving dynamic problems described by Judd (1992). The algorithm is programmed in FORTRAN77 and employs NAG subroutines.

My goal is to solve the set of first order conditions for the dynamic programming problem defined in section 2, which are the following:

$$
\begin{aligned}
& \frac{\partial V}{\partial s}=-U_{g}+\beta E\left[V^{a}\right]\left(1-\psi^{h}\right)=0 \text { if } \mathrm{s}>0(<0 \text { if } \mathrm{s}=0), \\
& \frac{\partial V}{\partial b}=-U_{m}+\beta E\left[V^{w}\right](1+r)=0 \text { if } \mathrm{b}>0 \quad(<0 \text { if } \mathrm{b}=0) \\
& \frac{\partial V}{\partial g p}=U_{g}-U_{m} p(1+\tau)=0 \quad \text { if } g \mathrm{p}>0 \text { and gs }=0 \quad(<0 \text { if gp }=0), \\
& \frac{\partial V}{\partial g s}=-U_{g}+U_{m} p(1-\tau)=0 \text { if gs }>0 \text { and gp }=0 \quad(<0 \text { if } g s=0) \text {, and } \\
& \frac{\partial V}{\partial \mathbf{z}^{g}}=E\left[V^{a} \frac{\partial g}{\partial \mathbf{z}^{g}}(\theta)\right]+E_{t}\left[V^{w} \frac{\partial c}{\partial \mathbf{z}^{g}}(\theta)\right]=0 \quad 0<\mathrm{z}^{\mathrm{g}}<\mathrm{z} \quad\left(>0 \text { if } \mathrm{z}^{\mathrm{g}}=\mathrm{z},<0 \text { if } \mathrm{z}^{\mathrm{g}}=0\right) .
\end{aligned}
$$


The subscripts on $U$ and superscripts on $V$ denote partial derivatives. This system of equations describes highly intuitive marginal conditions, but all of the control variables have inequality constraints, which makes the problem highly nonlinear and precludes analytical solutions.

The algorithm has ten steps for finding internally consistent, forward-looking behavior:

1. Make guesses (Chebyshev polynomial approximations) for the two marginal expected utility (value) functions with respect to household grain availability and wealth. Define these as functions of household storage, bond holding, and market storage:

$$
E_{t}\left[V_{t+1}^{a} \mid s_{t}, b_{t}, m s_{t}\right]=\varphi_{a}\left(s_{t}, b_{t}, m s_{t}\right) \text { and } E_{t}\left[V_{t+1}^{w} \mid s_{t}, b_{t}, m s_{t}\right]=\varphi_{w}\left(s_{t}, b_{t}, m s_{t}\right)
$$

2. Pick a starting grid over which the above functions are defined.

Choose $\mathrm{J}$ values for $s_{\mathrm{t}}: s_{\mathrm{t}}^{\mathrm{i}}$ where $\mathrm{j}=1,2, \ldots, \mathrm{J}$.

Choose $\mathrm{K}$ values for $b_{\mathrm{t}}: b_{\mathrm{t}}{ }^{\mathrm{i}}$ where $\mathrm{k}=1,2, \ldots, \mathrm{K}$.

Choose $\mathrm{L}$ values for $m s_{\mathrm{t}}: m s_{\mathrm{t}}^{\mathrm{i}}$ where $\mathrm{l}=1,2, \ldots, \mathrm{L}$.

It is best to choose values that are Chebyshev zeroes rather than a uniform grid (Judd, 1992).

3. Guess a production level $x$ for ${Z_{\mathrm{t}+1}}^{\mathrm{g}}$ and multiply this level by the different possible production shocks $\left(1+\alpha_{1} \dot{\theta}+\alpha_{2} \theta^{\mathrm{g}}\right)$, where $\mathrm{i}=1,2, \ldots, \mathrm{I}$ and $\mathrm{g}=1,2, \ldots, \mathrm{G}$.

4. For each starting storage amount $s_{\mathrm{t}}^{\mathrm{j}}$ and each possible shock realization, calculate the J x I x G possible next period starting availabilities:

$$
a_{t+1}^{j i a}=s_{t}^{j}\left(1-\psi^{h}\right)+x\left(1+\alpha_{1} \theta^{i}+\alpha_{2} \theta^{g}\right)
$$

Similarly, for each starting bond amount $b_{\mathrm{t}}^{\mathrm{i}}$, calculate the K next period starting wealth levels:

$$
w_{t+1}^{k}=b_{t}^{k}(1+r)+c(z-x) \text {. }
$$

5. Finally, for each starting market carryover $m s_{\mathrm{t}}{ }^{\mathrm{k}}$, determine the $\mathrm{L}$ x G market availabilities next period given different shocks: 


$$
m a_{t+1}^{l a}=m s_{t}^{l}\left(1-\psi^{m}\right)+m x_{t}^{l}\left(1+\theta^{a}\right) .
$$

Only the aggregate shock hits the market as a whole. Optimal market production for next period $\left(m x_{\mathrm{t}}^{\mathrm{k}}\right)$ can be solved for as in the model of Wright and Williams (1982) and will depend on the market carryover. Knowing the policy rule for storage next period, each possible market availability next period will be associated with a market price, so that essentially we have the following implicit function:

$$
p_{t+1}^{k a}=f\left(m a_{t+1}^{k a}\right)=f\left(m s_{t}^{k}, \theta^{a}\right)
$$

See Williams and Wright (1991) for a detailed explanation for how this model is solved. The essential algorithm is the same as that used to solve the household model, but in one rather than three dimensions.

6. For each combination of starting grain availabilities, starting wealth, and starting market availability, solve the first four first order conditions of the stochastic dynamic programming problem. This highly nonlinear system of equations is solved using nested iterative Newton search algorithms. Use the approximated functions in step 1 for the expected marginal value functions in the first order conditions for storage and bond holding. This system of equations determines the optimal levels of storage, bond holding, and trade given the values of the three states ( $t+1$ subscript suppressed):

$$
\begin{aligned}
& \frac{\partial V}{\partial s}=-v(w-b+p(g s(1-\tau)-g p(1+\tau)))^{1-R}(a-s+g p-g s)^{v(1-R)-1} \\
& +\beta\left(1-\psi^{h}\right) \varphi_{a}(s, b, S)=0 \quad \text { if } s>0 \quad(\leq 0 \quad \text { if } s=0), \\
& \frac{\partial V}{\partial b}=-(w-b+p(g s(1-\tau)-g p(1+\tau)))^{-R}(a-s+g p-g s)^{v(1-R)} \\
& +\beta(1+r) \varphi_{w}(s, b, m s)=0 \quad \text { if } b>0 \quad(\leq 0 \quad \text { if } b=0), \\
& \frac{\partial V}{\partial g p}=(w-b+p(g s(1-\tau)-g p(1+\tau)))^{-R}(a-s+g p-g s)^{v(1-R)-1}
\end{aligned}
$$




$$
\begin{gathered}
{\left[v^{*}(w-b+p(g s(1-\tau)-g p(1+\tau)))-(a-s+g p-g s) p(1+\tau)\right]=0} \\
\text { if } g p>0 \quad(\leq 0 \text { if } g p=0) \quad \text { when } g s=0, \text { and } \\
\frac{\partial V}{\partial g s}=(w-b+p(g s(1-\tau)-g p(1+\tau)))^{-R}(a-s+g p-g s)^{v(1-R)-1} \\
{\left[(a-s+g p-g s) p(1-\tau)-v^{*}(w-b+p(g s(1-\tau)-g p(1+\tau)))\right]=0} \\
\text { if } g p>0 \quad(\leq 0 \text { if } g s=0) \quad \text { when } g p=0
\end{gathered}
$$

7. Knowing the optimal solution for period $\mathrm{t}+1$ control variables for all possible state realizations allows us to calculate the expected marginal utility for different values for period t controls:

$$
\begin{gathered}
E_{t}\left[U_{t+1}^{a} \mid s_{t}^{j}, b_{t}^{k}, m s_{t}^{l}\right]=\sum_{i=1}^{I} \sum_{g=1}^{G} v^{*}\left(a_{t+1}^{j i g}-s_{t+1}^{j k l i g}+g p_{t+1}^{j k l i g}-g s_{t+1}^{j k l i g}\right)^{v(1-R)-1} \\
E_{t}\left[U_{t+1}^{w} \mid s_{t}^{j}, b_{t}^{k}, m s_{t}^{l}\right]=\sum_{i=1}^{I} \sum_{g=1}^{G}\left(a_{t+1}^{j i g}-s_{t+1}^{j k l i g}+g p_{t+1}^{j k l i g}-g s_{t+1}^{j k l i g}\right)^{v(1-R)} \\
\left(w_{t+1}^{k}-b_{t+1}^{j k l i g}+p_{t+1}^{\mathrm{lg}}\left(m s_{t}^{l}, \theta^{g}\right)\left(g s_{t+1}^{j k l i g}(1-\tau)-g p_{t+1}^{j k l i g}(1+\tau)\right)\right)^{-R} \operatorname{prob}\left(\theta^{g}\right) \operatorname{prob}\left(\theta^{i}\right), \text { and } \\
E_{t}\left[U_{t+1}^{a}\left(1+\alpha_{1} \theta^{i}+\alpha_{2} \theta^{t}\right) \mid s_{t}^{j}, b_{t}^{k}, m s_{t}^{l}\right]=\sum_{i=1}^{I} \sum_{g=1}^{G}\left(1+\alpha_{1} \theta^{i}+\alpha_{2} \theta^{t}\right) v^{*}\left(a_{t+1}^{j i g}-s_{t+1}^{j k l i g}+g p_{t+1}^{j k l i g}-g s_{t+1}^{j k l i g}\right)^{v(1-R)-1} \\
\left(w_{t+1}^{k}-b_{t+1}^{j k l i g}+p_{t+1}^{\lg }\left(m s_{t}^{l}, \theta^{g}\right)\left(g s_{t+1}^{j k l i g}(1-\tau)-g p_{t+1}^{j k l i g}(1+\tau)\right)\right)^{1-R} \operatorname{prob}^{j}\left(\theta^{g}\right) p r o b\left(\theta^{i}\right) .
\end{gathered}
$$

The last expression is the marginal utility analog to the producer incentive price. It accounts for correlation between output realization and marginal utility just as profitmaximizing producers will consider output-price covariance.

8. By the Envelope Theorem, these expressions for expected marginal utility are equivalent to expected marginal value functions. This makes it possible to test the final first order condition (determining production) for each starting grid value:

$$
\frac{\partial V^{a}}{\partial z^{g}}=E_{t}\left[V^{a}\left(1+\alpha_{1} \theta^{i}+\alpha_{2} \theta^{g}\right)\right]-c E_{t}\left[V^{a}\right]=0 \text { when } 0<z^{g}<z
$$


If this condition does not hold, we choose another guess for optimal resource allocation $x$ (again using a Newton search algorithm) and repeat steps 3-8 until convergence. Because the resource allocation decision does not affect current utility, it need not be solved for explicitly in step 6. Optimal $x$ is uniquely determined by choices for $s_{t}, b_{t}$, and market carryovers $S_{\mathrm{t}}$, which is implicitly being tested here.

9. Once the condition in step 8 is met, the expected marginal utilities calculated in step 7 $\left(\mathrm{E}_{\mathrm{t}}\left[U^{\mathrm{a}}\right]\right.$ and $\left.\mathrm{E}_{\mathrm{t}}\left[U^{\mathrm{w}}\right]\right)$ for each starting grid value $\left(s_{\mathrm{t}}^{\mathrm{j}}, b_{\mathrm{t}}{ }^{\mathrm{k}}\right.$, and $\left.S_{\mathrm{t}}{ }^{\mathrm{l}}\right)$ can be fitted to polynomials which can be expressed as

$$
\varphi_{a}^{*}\left(s_{t}, b_{t}, S_{t}\right) \text { and } \varphi_{w}^{*}\left(s_{t}, b_{t}, S_{t}\right) \text {. }
$$

10. Compare the fitted polynomials in step 9 to the original guesses in step 1. If they differ, repeat all steps with the newly fitted polynomials. This recursive substitution is certain to converge and can be thought of as analagous to specifying a terminal marginal value function for the last period of a finite-time problem and solving recursively for marginal value functions in previous periods until the end point is so distant that the functions are essentially time-unvarying. Projection methods (Judd, 1992) may converge faster but with less assurance that convergence will occur. 


\section{Appendix 2}

\section{Sensitivity Analysis}

In this appendix, I discuss the results of simulations for which key parameter assumptions concerning preferences, technology, and market demand and supply elasticities are altered. The new parameter values and mean values for the grain management variables of interest are presented in Appendix Table 1.

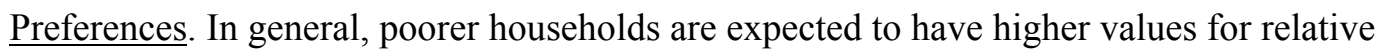
risk aversion, rate of time preference, and grain consumption share. New simulations are run for high and low values of each preference parameter. New parameter values are as follows: 2 and 5 for $\mathrm{R}, 0.08$ and 0.20 for $\delta$, and 0.3 and 0.7 for $\gamma$. As risk aversion increases, there is a desire to increase precautionary savings, but also to substitute grain storage for bonds to hedge against price risk. For grain, the cumulative effect is unambiguous (in the high risk aversion case increasing by over 30\%) while for bond holding, the two effects are opposite. There is similar ambiguity over marketing and production decisions, with grain purchases and grain sown area being slightly higher in the base case than in either the high or low risk aversion cases. Higher rates of time preference result in reduced storage of grain, lower bond holding, fewer grain purchases and sales, and reduced grain sown area. Altering the rate of time preference has a much more pronounced effect on bond holding (for the high value, bond holding increases by $13 \%$ ) than on grain storage, suggesting that grain storage is held more for hedging purposes and bonds more for pure intertemporal smoothing. When grain consumption share increases, the household's grain storage, production, and trade as shares of grain consumption do not change much, but bond holding as a share of marketed goods consumption increases, so that overall precautionary savings rise. These results suggest that risk aversion has the greatest effect on grain storage behavior while bond-holding responds more to the household's rate of time preference 
and the grain consumption share. Asset choices seem more responsive to changes in preferences than the production decision.

Technology coefficient. Average precautionary saving increases monotonically with the relative return to cash crop cultivation, but holdings of individual assets (grain and bonds) do not. Grain stocks rise with relative return, then fall; bonds fall, then rise. Individual assets vary nonmonotonically because of the tradeoffs between aggregate and substitution effects. In this case, as the return to cash crop production increases, the amount of sown area to grain falls. Incomes are higher but exposure to grain consumption risk is also higher. The higher risk exposure leads to higher precautionary saving. But as incomes and savings rise, there is less willingness to hold grain. Similarly, at low relative returns, grain production is so high that the household also substitutes away from grain in favor of bonds. Hence, the $U$ and inverted-U shapes of bond and grain holding with respect to the return coefficient.

Market demand and supply elasticities. As the rural economy develops, one expects market demand and supply to become more elastic. With more elastic demand, supply shocks have smaller price effects and price variability decreases. The price coefficient of variation for the high elasticity case is 0.16 compared to 0.24 for the base case. Facing less price risk, the household stores less grain. Production, however, is lower in both the high and low elasticity cases. In the high elasticity case, there is a slight reduction because lower grain price variability implies fewer periods of high prices in which grain can be grown profitably. In the low elasticity case, production is used less as grain storage is used more. The effects of changes in market supply elasticity are less clear. The correlation of price with yield shock depends on the demand elasticity, not the supply elasticity. The elastic supply case is associated with a price coefficient of variation of 0.22 compared to 0.27 for inelastic supply, but grain management variables do not change appreciably or monotonically. This is because in the inelastic case, the high price variation leads the market to store more grain on average and incidence of market stock outs is 
less. The household may even be less vulnerable to very high prices even though price variation is higher. 


\section{Endnotes}

${ }^{1}$ Renkow captures the consumption motive for stock-holding in arbitrarily specified function for the cost and convenience of storage and does not consider the precautionary motive for grain storage. The models of risk and production and Saha (1994) are static or two period models that characterize risk through variance and covariance terms, and which do not fully capture realistic joint distributions for yields and prices.

${ }^{2}$ Other papers look at risk and the holding of productive assets such as bullocks (Rosenzweig and Wolpin, 1993), tubewells (Fafchamps and Pender, 1997), and land (Carter and Zimmerman, 2000; Zimmerman and Carter, 2003).

${ }^{3}$ Such kinks can be handled by grid search or spline functions, but only at high computational cost. For problems with one or two state variables, this approach may be feasible, but at higher dimensions, computational cost becomes prohibitive.

${ }^{4}$ Wealth shares do not account for cash on hand or savings deposits, for which reliable data could not be collected. Village leaders reported that only about a third of households hold savings deposits.

${ }^{5}$ Calculated from survey data as net income (output value-intermediate inputs) divided by labour or land. Chinese national cost of production data also suggest significantly higher returns to soybean cultivation.

${ }^{6}$ The three counties are Yanan Municipality of Yanan Prefecture, Yulin Municipality of Yulin Prefecture, and Shang County of Shangluo Prefecture.

${ }^{7}$ Fafchamps and Pender (1997) estimate relative risk aversion of 2.8 to 2.9 for households in Kanzara village in India (ICRISAT). Binswanger (1980) reports much higher rates of 6.98 to 18.8 using experimental data from Indian farmers. Morduch (1990) and Rosenzweig and Wolpin (1993) estimate lower rates of 1.39 and 0.964 for households in the ICRISAT villages. Zeldes (1989) finds rates of 2.3 and 2.7 for U.S. households. According to Morduch (1990) the range estimated by Auerbach and Kotlikoff for U.S. households is 0.5 to 4.0. All of these are with respect to income. One would expect risk aversion with respect to a staple grain for poor households to be higher.

${ }^{8}$ Almost all food expenditures are on grain, grain-related products, or other self-produced agricultural products also affected by yield shocks. Food expenditures shares in poor c counties reach $70 \%$ based on available SSB data from 6 poor counties.

${ }^{9}$ The official deposit rate at banks and rural credit cooperatives (RCCs) is close to zero in real terms while loans from RCCs are at $4.7 \%$ real interest. Some, but not all, villages report informal lending at positive real interest rates averaging $14 \%$.

${ }^{10}$ Simulations test the sensitivity of the results to changes in the difference in returns (Park, 1996). The $20 \%$ base case parameterization is lower than that reflected in the simple returns calculated from household data to account for the fact that low return grain crops such as millet, sorghum, and potatoes are frequently grown on poor quality land and so bias grain returns downward. Also, soybean, the main cash crop, is often intercropped with corn, which is planted earlier, and benefits from labour and fertilizer attributed to corn.

${ }^{11}$ The range of estimated demand and supply elasticities for grain crops in developing countries is rather wide (Tsakok, 1990). A relatively low demand elasticity is likely for a necessity such as grain. Simulations under these elasticity assumptions produce a coefficient of variation of price of 0.24 , slightly greater than the estimated 0.19 for county grain prices.

${ }^{12}$ An exception is the nonlinear, dynamic models of livestock production (Rosen, 1987; Rosen, Murphy, and Scheinkman, 1994).

${ }^{13}$ Fafchamps (1992) identifies two portfolio effects at play for risk-averse households allocating resources between staples and cash crops -- a traditional portfolio effect that balances the expected level and variability of income, and a consumption effect due to the desire to produce 
more of the staple to hedge against price risk when the staple comprises a significant share of expenditures. Simulations show that if the household is a risk-averse producer and does not consume grain, it specializes in the cash crop. This implies that positive grain production by the household in the base case is fully attributable to the consumption role of grain.

${ }^{14}$ I approximate the value of precautionary saving by valuing grain at its average price of 1 . This will slightly overestimate the actual value, since more grain stocks are generally held at lower prices.

${ }^{15}$ In these simulations, the shocks and probability distributions are as follows:

\begin{tabular}{|c|c|c|c|}
\hline \multicolumn{2}{|c|}{ symmetric distribution } & \multicolumn{2}{|c|}{ asymmetric distributior } \\
\hline shock & Prob & $\underline{\text { Shock }}$ & Prob \\
\hline-0.17 & 0.30 & -0.40 & 0.05 \\
\hline 0.00 & 0.40 & -0.10 & 0.475 \\
\hline 0.17 & 0.30 & 0.10 & 0.475 \\
\hline
\end{tabular}

${ }^{16} \mathrm{We}$ can also see why storage is zero from the first order conditions of the Bellman equation for optimal storage and bond-holding:

$$
\begin{gathered}
\frac{\partial V}{\partial s}=-U_{g}+\beta E\left[V^{a}\right]\left(1-\psi^{h}\right)=0 \text { if } \mathrm{s}>0(<0 \text { if } \mathrm{s}=0) \text {, and } \\
\frac{\partial V}{\partial b}=-U_{m}+\beta E\left[V^{w}\right](1+r)=0 \text { if } \mathrm{b}>0(<0 \text { if } \mathrm{b}=0) .
\end{gathered}
$$

When grain purchases are positive, $U_{g}-U_{m}(1+\tau)=0$ (Appendix 1). Similarly, by an envelope condition, expected marginal value functions equal expected marginal utility functions, so that:

$$
E\left[V^{a}\right]=E\left[-U_{g}\right]=E\left[-U_{m}(1+\tau)\right]=E\left[V^{W}\right](1+\tau) .
$$

After substitution and multiplication by $(1+\tau)$, the first order condition for bond-holding can be rewritten as follows:

$$
\frac{\partial V}{\partial b}=-U_{g}+\beta E\left[V^{g}\right](1+r)=0 \text { if } \mathrm{b}>0 \quad(<0 \text { if } \mathrm{b}=0) .
$$

Comparing this to the first order condition for grain storage reveals that it must be the case that $\frac{\partial V}{\partial b}>\frac{\partial V}{\partial s}$. But this means that $\frac{\partial V}{\partial s}<0$, so storage must equal zero.

${ }^{17}$ Production under price uncertainty was studied by Sandmo (1971), and extended to the household model by Finkelshtain and Chalfant (1991). Fafchamps (1992) studied household production under both yield and price risk, and Williams and Wright (1991) examine production and storage under price and yield risk for a profit-maximizer.

${ }^{18}$ For a purchaser, the producer price is determined by adding the saved transaction cost to the market price while for a seller, the transaction cost is subtracted. In autarky, the producer price is a shadow price that is not market-determined. The market participation decision, in turn, depends on the solution to the household's full optimization problem, including the production decision. Generally, the more grain produced, the lower the producer incentive price, since higher grain output implies greater likelihood of a buyer becoming autarkic or a seller. With the producer incentive price falling monotonically with production in this way, the optimization problem of a profit-maximizer is analagous to that of a monopolist. Solving this problem yields the production and expected profit levels for a profit maximizer when all other decisions are held constant at their utility-maximizing values. These levels serve as static efficiency benchmarks that ask, "Given these assets, the current market situation, and the anticipated price and yield realizations (and corresponding market participation decisions), what level of output maximizes expected profits with price measured at the farm gate?" 
${ }^{19}$ For simulations in which preference parameters (relative risk aversion, rate of time preference, and grain consumption share) are all increased to mimic a "poorer" household (see appendix 2 for parameter values), the efficiency loss in income units increases from 1.69 to only 2.10 , about $2 \%$ of production income. For different parameter values for the relative return to cash crop production, the highest efficiency loss is 3.42 when the returns to cash crop and grain production are equal. 
Fig. 1: Model Timeline

State (t)

Decision variables ( $t$ )

Uncertainty Realization

State $(t+1)$

\section{Household}

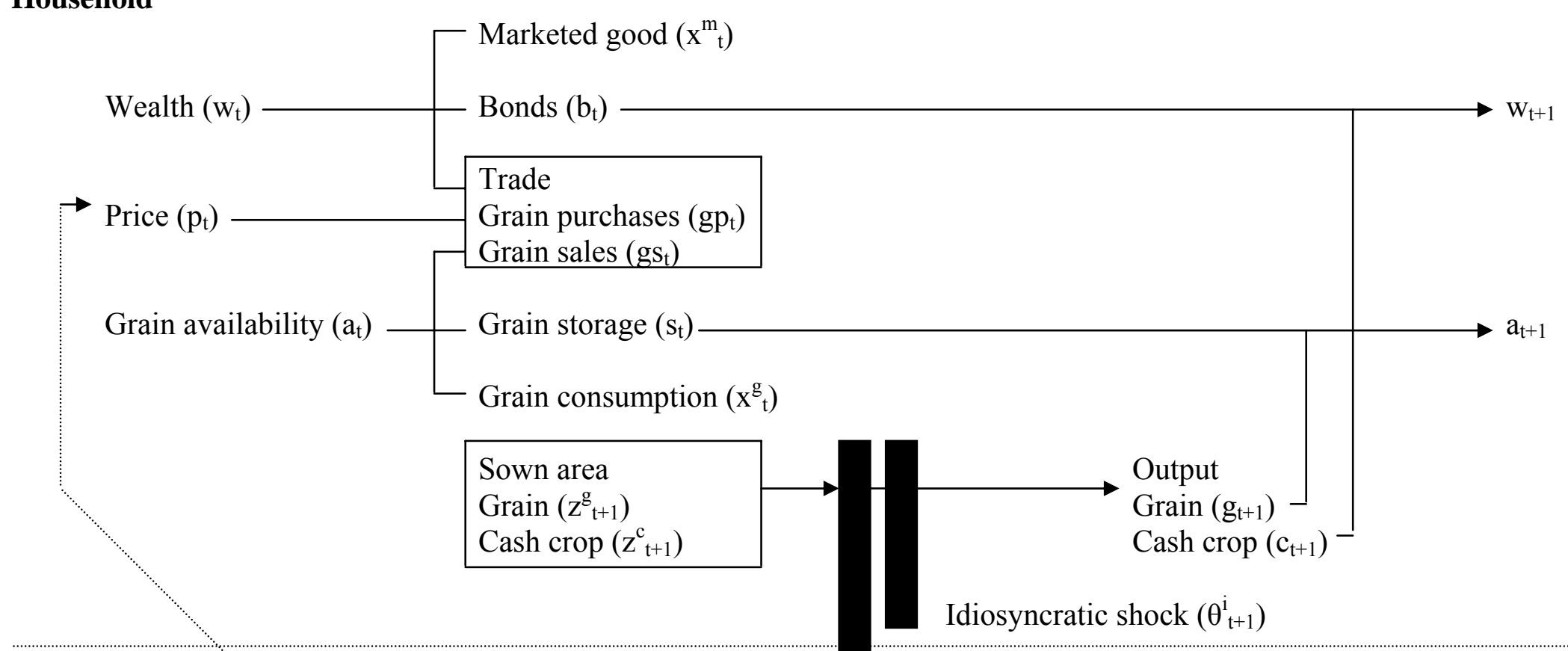

Grain Market

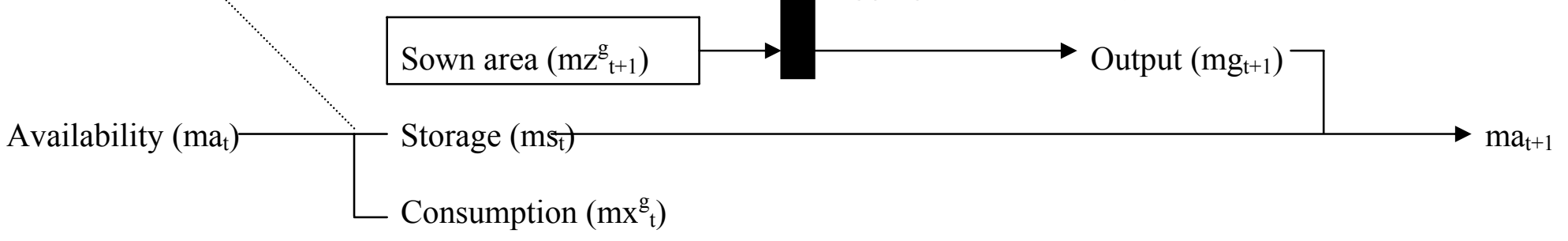


Fig. 2

Price Response Curves with Low Grain Availability and Wealth $(a=35, w=40)$

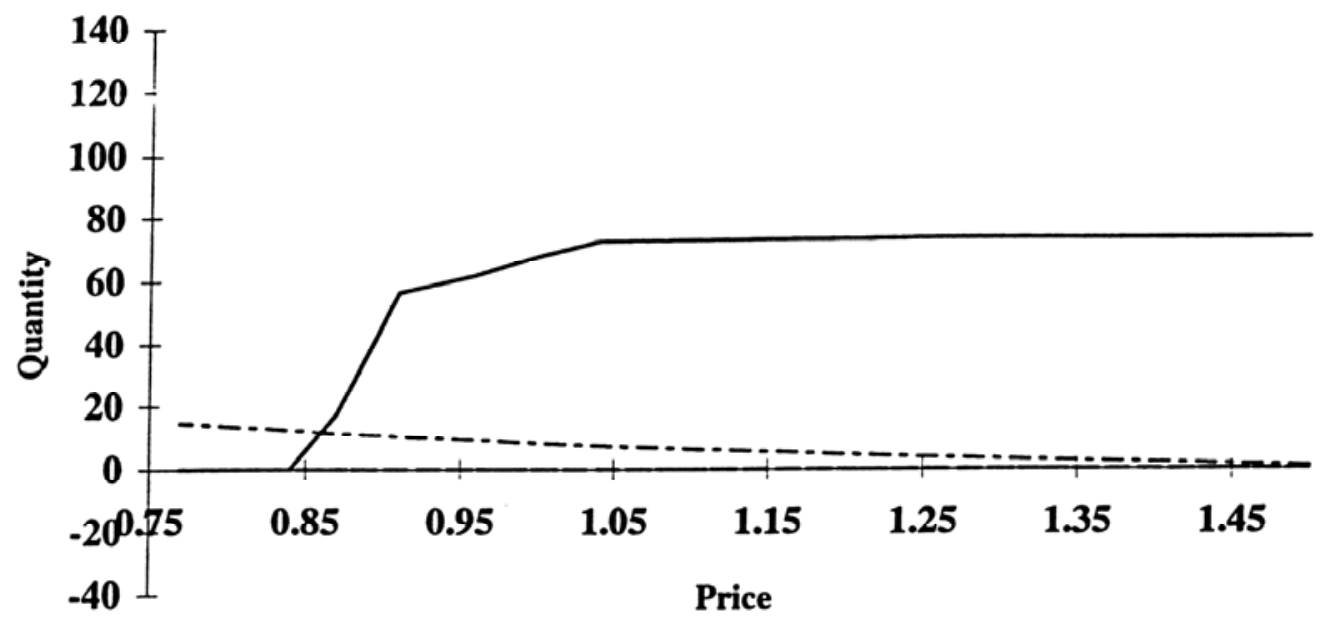

---- Grain storage $\cdot . . . .$. Bonds $-\cdot-\cdot-$ Net grain purchases - Grain sown area 
Fig. 3

Price Response Curves with High Grain Availability and Wealth ( $a=105, w=170)$

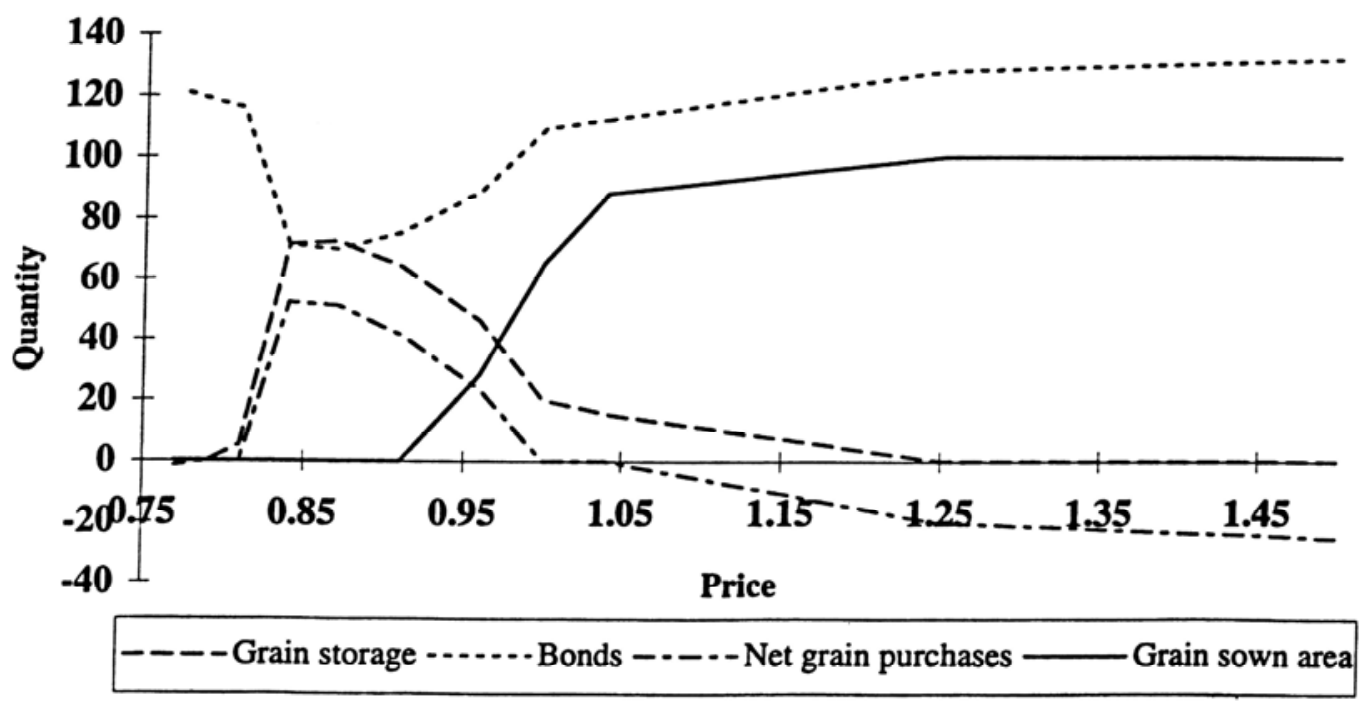


Table 1

Parameter Values for the Household Model

\begin{tabular}{lcc}
\hline Definition & $\begin{array}{c}\text { Parameter } \\
\text { Symbol }\end{array}$ & Value \\
\hline Relative risk aversion & $\mathrm{R}$ & 3.00 \\
Consumption share parameter & $\gamma$ & 1.50 \\
Rate of time preference & $\delta$ & 0.10 \\
Interest rate return on bonds & $\mathrm{r}$ & 0.08 \\
Storage proportional cost (spoilage rate) & $\psi^{\mathrm{h}}$ & 0.03 \\
Resource availability & $\mathrm{z}$ & 100 \\
Cash crop/grain expected yield ratio & $\mathrm{c}$ & 1.20 \\
Market transaction cost & $\tau$ & 0.08 \\
Idiosyncratic shock weight & $\alpha_{1}$ & 1.20 \\
Aggregate shock weight & $\alpha_{2}$ & 1.00 \\
\hline
\end{tabular}


Table 2

Base Case Scenario Summary Statistics

(1000-Period Simulation)

\begin{tabular}{|c|c|c|c|c|c|c|}
\hline & Mean & Lowest & Highest & $\begin{array}{l}\text { Standard } \\
\text { Deviation }\end{array}$ & $\begin{array}{l}\text { Coef. of } \\
\text { Variation }\end{array}$ & Zeroes* \\
\hline Grain storage (s) & 23.8 & 0.0 & 85.6 & 25.8 & 1.08 & 0.38 \\
\hline Bonds $(b)$ & 29.5 & 0.0 & 105.4 & 26.9 & 0.9 & 0.24 \\
\hline Grain purchases (gp) & 31.6 & 0.0 & 158.0 & 37.4 & 1.18 & 0.34 \\
\hline Grain sales (gs) & 2.5 & 0.0 & 47.6 & 8.0 & 3.16 & 0.86 \\
\hline Grain sown area $\left(z^{g}\right)$ & 37.7 & 0.0 & 100.0 & 38.8 & 1.03 & 0.43 \\
\hline Grain output $(g)$ & 38.2 & 0.0 & 137.4 & 40.9 & 1.10 & \\
\hline Cash crop output $(c)$ & 74.7 & 0.0 & 164.9 & 49.6 & 0.66 & \\
\hline $\begin{array}{l}\text { Yield shock multiplier } \\
(\theta)\end{array}$ & 1.00 & 0.63 & 1.37 & 0.20 & 0.20 & \\
\hline Grain consumption $\left(x^{g}\right)$ & 66.5 & 34.9 & 118.5 & 11.4 & 0.17 & \\
\hline $\begin{array}{l}\text { Marketed good } \\
\text { consumption }\left(x^{m}\right)\end{array}$ & 44.9 & 30.7 & 64.4 & 4.8 & 0.11 & \\
\hline Income & 112.9 & 72.4 & 162.7 & 19.3 & 0.17 & \\
\hline Grain availability (a) & 61.2 & 0.0 & 137.4 & 30.9 & 0.51 & \\
\hline Wealth $(w)$ & 100.6 & 18.4 & 238.8 & 47.1 & 0.47 & \\
\hline Market price $(p)$ & 1.01 & 0.76 & 1.64 & 0.24 & 0.24 & \\
\hline Market storage (ms) & 12.4 & 0.0 & 37.8 & 10.1 & 0.82 & 0.20 \\
\hline
\end{tabular}

* Zeroes are share of total periods for which value equals zero. 
Table 3

Base Case Comparison with Credit Access, No Price Risk, and No Asset Scenarios (Means for 1000-Period Simulation)

\begin{tabular}{|c|c|c|c|c|}
\hline & Base Case & Credit Access* & No Price Risk & No Asset \\
\hline Grain storage & 23.8 & 21.5 & 0.0 & 0.0 \\
\hline Bonds & 29.5 & 12.5 & 40.3 & 0.0 \\
\hline Grain purchases & 31.6 & 30.7 & 63.2 & 24.1 \\
\hline Grain sales & 2.5 & 2.7 & 0.0 & 7.0 \\
\hline Grain sown area & 37.7 & 37.8 & 0.0 & 47.6 \\
\hline $\begin{array}{l}\text { Grain } \\
\text { consumption }\end{array}$ & 66.5 & 65.7 & 65.2 & 65.3 \\
\hline $\begin{array}{l}\text { Marketed good } \\
\text { consumption }\end{array}$ & 44.9 & 44.3 & 45.5 & 42.0 \\
\hline Income & 112.9 & 111.3 & 113.7 & 107.4 \\
\hline
\end{tabular}

*The household can borrow up to 20 units of income.

Table 4

Profit-Maximizing and Utility-Maximizing Production Decisions (Means for 1000-Period Simulation of Base Case Scenario)

\begin{tabular}{lccc}
\hline & Profit- & Utility- & \\
& Maximizing & Maximizing & Difference \\
\hline Expected Production Income & 111.41 & 109.48 & 1.93 \\
Grain Sown Area & 14.89 & 37.60 & 22.71 \\
\hline
\end{tabular}




\section{Appendix Table 1 \\ Sensitivity Analysis \\ Mean Values for 1000-Period Simulations}

\begin{tabular}{|c|c|c|c|c|c|c|c|}
\hline & $\begin{array}{l}\text { Base } \\
\text { case } \\
\text { value }\end{array}$ & $\begin{array}{c}\text { New } \\
\text { parameter } \\
\text { value }\end{array}$ & $\begin{array}{l}\text { Grain } \\
\text { storage } \\
\text { (s) }\end{array}$ & $\begin{array}{c}\text { Bonds } \\
\text { (b) }\end{array}$ & $\begin{array}{c}\text { Grain } \\
\text { purchases } \\
\text { (gp) }\end{array}$ & $\begin{array}{c}\text { Grain } \\
\text { sales } \\
\text { (gs) }\end{array}$ & $\begin{array}{c}\text { Grain } \\
\text { sown area } \\
\left(\mathrm{z}^{\mathrm{g}}\right)\end{array}$ \\
\hline Base case & & & 24 & 30 & 32 & 3 & 38 \\
\hline \multirow[t]{2}{*}{ Risk aversion (R) } & 3 & 2 & 18 & 34 & 33 & 2 & 35 \\
\hline & & 5 & 31 & 33 & 35 & 3 & 35 \\
\hline \multirow{2}{*}{$\begin{array}{l}\text { Rate of time } \\
\text { preference }(\delta)\end{array}$} & 0.10 & 0.08 & 24 & 33 & 32 & 3 & 38 \\
\hline & & 0.20 & 23 & 23 & 31 & 2 & 38 \\
\hline \multirow{2}{*}{$\begin{array}{l}\text { Grain consumption } \\
\text { share }(\gamma)\end{array}$} & 1.5 & 0.5 & 15 & 37 & 18 & 2 & 22 \\
\hline & & 2.0 & 28 & 29 & 36 & 2 & 40 \\
\hline \multirow{4}{*}{$\begin{array}{l}\text { Relative return to } \\
\text { cash crop (c) }\end{array}$} & 1.2 & 1.0 & 10 & 28 & 1 & 16 & 77 \\
\hline & & 1.1 & 21 & 25 & 15 & 6 & 54 \\
\hline & & 1.3 & 35 & 39 & 58 & 0 & 15 \\
\hline & & 1.4 & 27 & 49 & 70 & 0 & 8 \\
\hline Risk discretization* & & & 43 & 31 & 39 & 5 & 30 \\
\hline \multirow{2}{*}{$\begin{array}{l}\text { Market demand } \\
\text { Elasticity }\end{array}$} & -0.2 & -0.1 & 29 & 13 & 34 & 3 & 36 \\
\hline & & -0.5 & 20 & 35 & 32 & 0 & 34 \\
\hline \multirow{2}{*}{$\begin{array}{l}\text { Market supply } \\
\text { Elasticity }\end{array}$} & 0.5 & 0.2 & 20 & 33 & 33 & 3 & 38 \\
\hline & & 0.8 & 19 & 37 & 30 & 2 & 38 \\
\hline
\end{tabular}

* Base case distribution of yield shocks (same for idiosyncratic and aggregate shocks): -0.17 (prob=0.3), 0.0 (prob=0.4), 0.17 (prob=0.3). New, asymmetric distribution: $-0.40($ prob $=0.05),-0.10(\mathrm{prob}=0.475)$, $0.10($ prob $=0.475)$. 